\title{
Topographical Anatomy of the Blunthead Treesnake, Imantodes cenchoa (Linnaeus, 1758) (Colubridae: Xenodontinae)
}

\author{
Anatomía Topográfica de la Serpiente Bejucillo Cabezona, \\ Imantodes cenchoa (Linnaeus, 1758) (Colubridae: Xenodontinae) \\ "Gustavo Aveiro-Lins; "Oscar Rocha-Barbosa; ** Maria da Graça Salomão; \\ ${ }_{* * * *}$ Giuseppe Puorto \& *Mariana Fiuza de Castro Loguercio
}

AVEIRO-LINS, G.; ROCHA-BARBOSA, O.; SALOMÃO, M. G.; PUORTO, G. \& LOGUERCIO, M. F. C. Topographical anatomy of the blunthead treesnake, Imantodes cenchoa (Linnaeus, 1758) (Colubridae: Xenodontinae). Int. J. Morphol., 24(1):43-48, 2006.

SUMMARY: Imantodes cenchoa (Duméril, 1853) is an arboreal, nocturnal and oviparous xenodontine snake, which feeds on amphibians and lizards. It is found in Central and South America, including northern and central Brazil. In this work, we investigated the relationship between topographic anatomy and habitat in I. cenchoa. Twenty specimens (13 non pregnant females and 7 males) were examined. The topographic anatomy study was realized through observations of the internal anatomy, particularly the position and size of lung, heart, liver, left and right gonads and left and right kidneys. Results showed that all the organs are located in a posterior position in relation to the snout vent length (SVL). The centre of gravity is found at about 74\% of SVL in both males and females. In males, no positive allometry was observed among the positions of the organs. Negative allometry in females was observed regarding the position of the anterior tip of the left kidney, the anterior and posterior tips of the right kidney and in both ovaries. In males, negative allometry is present in the position of all the or gans. The distance between the last follicle and the cloaca was $8.78 \%$ of SVL. Our data corroborate the idea that the posterior position of all internal organs is linked to a habitat specialization of a snake, linking the arboreal species I. cenchoa with a relatively posterior internal topography.

KEY WORDS: Snakes; Ecomorphology; Anatomy; Allometry; Arboreality.

\section{INTRODUCTION}

Snakes represent one of the more varied taxa concerning specializations for habitat and niche occupation (Lillywhite, 1988). Such specializations include differences in body size, habits, feeding behaviour and reproduction, and have determined the wide geographic distribution, as well as the evolutionary success of this group (Greene, 1997; Pough et al., 1998). Habitat characteristics mean a pool of biotic and abiotic levels of complexity that influence and might direct natural selection on morphology and physiology of snake populations (Vitt \& Vangilder, 1983; Guyer \& Donnelly, 1990; Cadle \& Greene, 1993; Lillywhite \& Henderson, 1993).

The study on topographic anatomy usually search for relations between the position and morphology of internal organs and external measurements or structures such as ventral scales, helping in the location of these organs and at the same time working as habitat use indicators in snakes. Several authors have reported the existence of anatomical variation in arboreal, terrestrial and aquatic snakes (Lillywhite, 1988; Rocha-Barbosa et al., 1999; RochaBarbosa et al., 2000), particularly heart position and size of vascular lung (Lillywhite, 1987b), which reflect strategies to adapt to gravitational variations in those habitats. The heart lies nearer to the head to guarantee blood supply to the brain both in typical arboreal species (Lillywhite, 1985b; Lillywhite, 1985a; Lillywhite, 1987a; Lillywhite, 1988; Lillywhite \& Smits, 1992; Lillywhite, 1993; Lillywhite \& Henderson; Badeer, 1998), as well as in those which exhibit incipient arboreality, as is the case of Bothrops insularis.

Therefore, since morphological differences express ecological shifts, it would be logical to expect anatomical changes in other parts of the body other than the heart.

\footnotetext{
Laboratório de Zoologia de Vertebrados (Tetrapoda), Departamento de Zoologia/UERJ, IBRAG, Universidade do Estado do Rio de Janeiro, Rua São Francisco Xavier, 524, Maracanã, 20550-013, Rio de Janeiro, RJ - Brasil.

*** Laboratório de Herpetologia, Universidade do Estado do Rio de Janeiro, Rio de Janeiro, RJ - Brasil. obarbosa@uerj.br;

**** Museu Biológico do Instituto Butantan, Av. Vital Brazil, 1500, 05503-900, São Paulo, Brasil. mgsalomao@butantan.gov.br.
} 
However, little is known about the position, shape or volume of internal organs and its correlation to snake life history, particularly in tropical herpetofauna.

Imantodes cenchoa (Linnaeus, 1758) is a neotropical colubrid commonly known as blunt headed tree snake, and shows a special ability of moving quickly among branches (Greene). It is oviparous and during the night feeds on amphibians and lizards, especially anoles (Genus Anolis); (Robinson, 1977; Zug et al., 1979), whereas during the day it may be found hidden in bromeliads (Henderson \& Nickerson, 1976), where it may feed on lizard eggs (Landry et al., 1966). Imantodes cenchoa occurs from the Isthmus of Tehuantepec, region of Mexico through Central and South America, reaching Paraguay and Bolivia (Peters \& Orejas-Miranda, 1970).

This study aims to describe the topographic anatomy of I. cenchoa in an attempt to locate internal organs, as well as to define the position of the clutch in relation to the snout-vent length (SVL) and the ventral scales.

\section{MATERIAL AND METHOD}

Twenty adult specimens of Imantodes cenchoa (Linnaeus, 1758) (13 non-pregnant females and 7 males) were analyzed. All of them consisted of museum specimens from the collections Alphonse Richard Hoge, Instituto Butantan (IB) and Museu Nacional do Rio de Janeiro (MNRJ/UFRJ), Brazil.

To determine the centre of gravity of each specimen, the snakes are put on an aluminium tray. The straightness of the specimens is maintained by fine strings. A thread suspends the aluminium tray and slides gently till the point of equilibrium is reached. Such point (noted as the centre of gravity) is marked on the snake body. Later, this measure is converted into a proportion (\%) of SVL.

Dissections were made following the methodology described previously by (Gomes et al., 1989) and (Gomes $\&$ Puorto, 1993). This technique allows the observation, location and measurement of internal organs, both as absolute measurements and in relation to position and length along the SVL. The position and length of organs were also recorded relative to the ventral scale count, by numbering the ventral scales and recording the number of the ventral scale at both the anterior and posterior ends of the organ. Lung, heart, liver, gonads and kidneys were longitudinally measured.
In females, the stage of vitellogenesis and the distance between the last ovarian or oviductal follicle and the cloaca were taken and transformed into a SVL proportion for comparisons with data of terrestrial and aquatic snakes obtained in the literature. (See Shine (1988) for details).

The biometrical measurements of both males and females were analyzed separately and compared subsequently to test for sexual dimorphism. Data were fitted using the power equation $\mathrm{Y}=\mathrm{aX}^{\mathrm{b}}$ (Huxley, 1932), where dependent variable y represents the linear measurement and the independent variable $\mathrm{x}$ was the SVL. The problem of biased estimates of slopes of $\mathrm{Y}$ on $\mathrm{X}$ when both variables are subject to measurement error, was overcome using the slope of the principal axis of the standardized variables (reduced major axis, RMA) (Teissier, 1948; Sokal \& Rohlf, 1995). A t-test was used to test for significance of departure from a predicted slope examined with residual analysis (Wittink, 1988). Each regression slope was checked for departure from isometry (Gould, 1966).

Equations were determined considering males and females separately. The equality of two population regression coefficients was tested for males and females allometric coefficients (sexual dimorphism). This involves the use of Student's $\mathrm{t}(\mathrm{p}<0.05)$ in a fashion analogous to that of testing for differences between two population means. When the slopes of the males and females were not significantly different, then just one regression line was determined.

\section{RESULTS}

Biometrical data and regression analysis are presented in Tables I and II, respectively. Positive allometry was obtained for females regarding the following relationships: the end of the liver and left kidney, beginning and end of the heart and lung. In males, no positive allometry was verified. Negative allometry in females was observed for the beginning of the left kidney, beginning and end of right kidney and both ovaries. In males, negative allometry was obtained for all internal organs.

Band occurrence and band superposition of each organ (indicating the beginning and the end of each organ) takes into consideration ventral scales and SVL and are presented in Table III. In Imantodes cenchoa, the heart occupies a very anterior position, followed by other visceral organs (Fig.1). The centre of gravity was determined to be located in the medial position of the snake when total length is concerned. However, when SVL is taken into consideration, the centre of gravity is found posteriorly in both sexes (73.83\% SVL). 
Table I. Biometry of internal anatomy in Imantodes cenchoa, $\mathrm{n}=20$. (SD - standard deviation, X - mean, t - Student's t, p - probability.

\begin{tabular}{cl}
\multicolumn{1}{c}{ Variable } & \\
Heart & Initial \\
Lung & End \\
& Initial \\
Liver & End \\
& Initial \\
End \\
Right ovary/testis & Initial \\
& End \\
Left ovary/testis & Initial \\
& End \\
Right kidney & Initial \\
& End \\
Left kidney & Initial \\
& End
\end{tabular}

Males $(X \pm S D)$
$276.28 \pm 47.64$
$286.71 \pm 49.14$
$286.71 \pm 49.14$
$338.30 \pm 55.14$
$311.00 \pm 82.89$
$519.85 \pm 92.81$
$614.85 \pm 129.71$
$624.28 \pm 134.97$
$632.00 \pm 131.95$
$645.14 \pm 138.97$
$635.57 \pm 131.01$
$657.00 \pm 131.19$
$645.14 \pm 132.10$
$666.28 \pm 134.38$

Females $(\mathbf{X} \pm \mathbf{S D})$
$272.15 \pm 40.91$
$286.84 \pm 40.76$
$279.38 \pm 42.51$
$338.20 \pm 39.23$
$323.77 \pm 52.71$
$497.84 \pm 59.47$
$633.00 \pm 103.41$
$657.15 \pm 111.71$
$636.84 \pm 95.87$
$660.23 \pm 101.33$
$663.62 \pm 91.58$
$688.23 \pm 93.32$
$671.08 \pm 93.18$
$693.62 \pm 93.81$

\begin{tabular}{r}
\multicolumn{1}{c}{$\mathbf{c}$} \\
-0.28 \\
0.01 \\
-0.48 \\
0.00 \\
0.58 \\
-0.89 \\
0.47 \\
0.80 \\
0.13 \\
0.38 \\
0.77 \\
0.85 \\
0.70 \\
0.49
\end{tabular}

p

0.99

0.64

1.00

0.57

0.39

0.65

0.44

0.90

0.71

0.45

0.41

0.73

0.48

Table II. Regression lines using the equation $y=a x^{b}$, is the SVL and $Y$ is one of the internal organs, $\mathrm{n}=20$. ( $\mathrm{SVL}$ - snout-vent length). $\mathrm{p}$ - probability, $\mathrm{r}$ - coefficient of correlation.

\begin{tabular}{|c|c|c|c|c|c|c|c|}
\hline $\mathbf{x}$ & $\mathbf{y}$ & & Sex & $\mathbf{r}^{2}$ & $\mathbf{a}$ & b & $\mathbf{p}_{(0.05)}$ \\
\hline & & & males & 0,86 & 0,69 & $-189,29$ & 0,002 \\
\hline & & Initial & females & 0,82 & 0,54 & $-78,98$ & 0,000 \\
\hline \multirow[t]{3}{*}{ SVL } & Liver & & males & 0,84 & 0,76 & $-31,40$ & 0,004 \\
\hline & & End & females & 0,87 & 0,63 & 29,11 & 0,000 \\
\hline & & & males & 0,80 & 1,06 & $-123,53$ & 0,006 \\
\hline \multirow[t]{4}{*}{ SVL } & Left kidney & Initial & females & 0,73 & 0,91 & $-0,75$ & 0,000 \\
\hline & & & males & 0,81 & 1,08 & $-118,78$ & 0,006 \\
\hline & & End & females & 0,73 & 0,92 & 16,90 & 0,000 \\
\hline & & & males & 0,80 & 1,05 & $-127,65$ & 0,006 \\
\hline \multirow[t]{4}{*}{ SVL } & Right kidney & Initial & females & 0,77 & 0,92 & $-17,815$ & 0,000 \\
\hline & & & males & 0,82 & 1,06 & $-115,18$ & 0,005 \\
\hline & & End & females & 0,77 & 0,94 & $-6,07$ & 0,000 \\
\hline & & & males & 0,80 & 1,05 & $-132,83$ & 0,007 \\
\hline \multirow[t]{4}{*}{ SVL } & Left ovary/test is & Initial & females & 0,68 & 0,91 & $-33,19$ & 0,000 \\
\hline & & & males & 0,81 & 1,11 & $-165,42$ & 0,006 \\
\hline & & End & females & 0,73 & 0,99 & $-71,49$ & 0,000 \\
\hline & & & males & 0,76 & 1,01 & $-117,39$ & 0,011 \\
\hline \multirow[t]{4}{*}{ SVL } & Right ovary/testis & Initial 1 & females & 0,71 & 1,00 & $-104,00$ & 0,000 \\
\hline & & & males & 0,77 & 1,06 & $-146,96$ & 0,009 \\
\hline & & End & females & 0,75 & 1,11 & $-160,98$ & 0,000 \\
\hline & & & males & 0,98 & 0,42 & $-29,39$ & 0,000 \\
\hline \multirow[t]{4}{*}{ SVL } & Heart & Initial & females & 0,70 & 0,37 & 2,46 & 0,000 \\
\hline & & & males & 0,98 & 0,43 & $-29,32$ & 0,000 \\
\hline & & End & females & 0,66 & 0,38 & 4,97 & 0,000 \\
\hline & & & males & 0,98 & 0,43 & $-29,32$ & 0,000 \\
\hline \multirow[t]{3}{*}{ SVL } & Lung & Initial & females & 0,54 & 0,36 & 16,29 & 0,000 \\
\hline & & & males & 0,99 & 0,49 & $-18,69$ & 0,000 \\
\hline & & End & females & 0,87 & 0,42 & 29,50 & 0,004 \\
\hline
\end{tabular}


Table III. Band Occurrence. (SVL - snout-vent length). $\mathrm{n}=20$.

\begin{tabular}{llcccc} 
& & \multicolumn{2}{c}{ Band occurrence } & \multicolumn{2}{c}{ Band superposition } \\
& & SVL $(\%)$ & Ventral scale & SVL (\%) & Ventral scale \\
\hline Heart & Initial & $36-38$ & $98-100$ & 38 & \multirow{2}{*}{$98-100$} \\
& End & $38-40$ & $98-104$ & & \\
Lung & Initial & $37-40$ & $98-104$ & & \\
Liver & End & $45-47$ & $115-121$ & & \\
& Initial & $41-45$ & $106-116$ & & \\
Right ovary/testis & End & $67-70$ & $164-177$ & & \\
\multirow{4}{*}{ Left ovary/testis } & Initial & $82-88$ & $208-220$ & $84-89$ & $213-220$ \\
& End & $84-91$ & $214-226$ & & \\
Right kidney & Initial & $83-89$ & $215-224$ & $85-90$ & $222-224$ \\
& End & $85-92$ & $222-231$ & & \\
Left kidney & Initial & $86-92$ & $222-230$ & $77-92$ & $230-231$ \\
& End & $78-106$ & $232-240$ & & \\
& Initial & $87-93$ & $222-234$ & $89-93$ & $232-234$
\end{tabular}

All females analyzed were in primary vitellogenesis condition, with follicles reaching a maximum diameter 1.0 $\mathrm{cm}$ and did not present signs of vitello deposition. Despite the wide range of months included in the specimen sample (February, May, August and December), it was not possible to detect the period of secondary vitellogenesis and ovulation. The average distance between the last follicle and the cloaca was $64.79 \pm 8.16 \mathrm{~mm}(\mathrm{n}=6)$ which means $8.78 \% \mathrm{SVL}$ at the ventral scale number 220 .

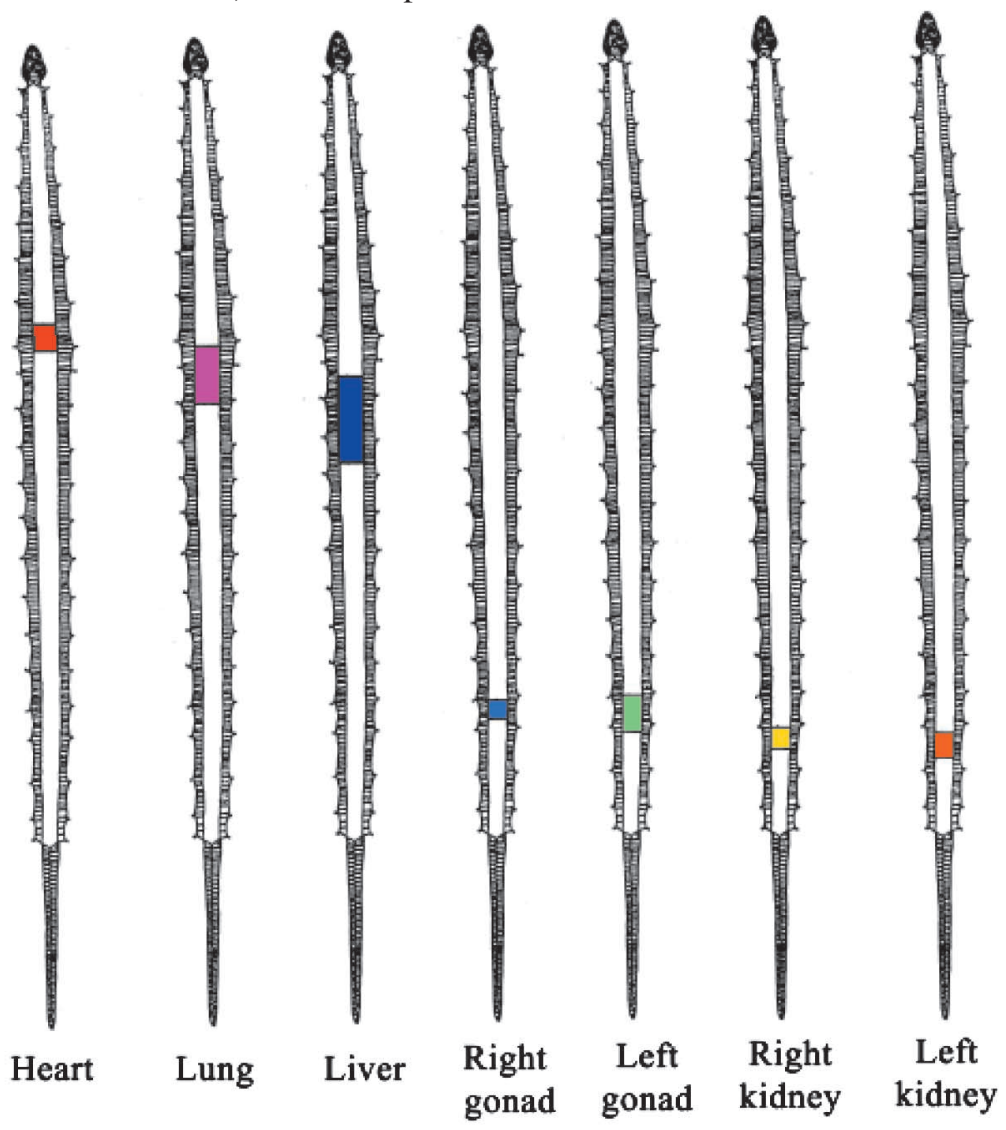

Fig. 1. Position of the internal organs in Imantodes cenchoa. The bands indicate the beginning and the end of each organ. 


\section{DISCUSSION}

Imantodes cenchoa is a snake whose body architecture shows almost all viscerae located in a posterior position relative to SVL, and a considerable space between the clutch and the cloaca, conditions which could facilitate locomotion on an arboreal habitat (Manzani, 1995). The weight of the animal, concentrated in the posterior part of the body, would serve as the main support for the snake, allowing the projection of the head and anterior part of the body without loss of equilibrium. This could speed up locomotion from branch to branch, and would enable the snake to strike agile prey more precisely, particularly lizards and amphibians (Young, 1982), the usual food items of the blunt headed tree snake.

In the field, we observed I. cenchoa supporting itself having only the last third of the body in contact with a branch, exactly the portion where the internal organs are concentrated. In this position the snake can easily project the head and the anterior part of the body forward very fast when capturing prey or escaping from predators.

Heart position may be constrained, due to the limited haemostatic control, lying in a more anterior position to ensure an adequate blood supply to the brain when the snake is tilted into a head-up position especially when climbing (Lillywhite \& Smits, 1992; Lillywhite, 1993; Lillywhite \& Henderson, 1993). Imantodes cenchoa assumes extreme vertical postures. However, our data show that its heart is located very posteriorly, about $36 \%$ SVL, opposed to the prediction of the authors mentioned above. Our findings agree with those of Manzani in which the heart is located between 11 and $42 \%$ $\mathrm{SVL}$ in arboreal snake representatives. Imantodes cenchoa is a member of the subfamily Xenodontinae, tribe Dipsadini, which includes other snakes with hearts in a posterior position (e.g., Leptodeira - Manzani), indicating that environmental pressures play a role as important as phylogeny in the determination of body structure.
Regarding the distance between the last follicle and the cloaca, our study indicates a wide space left over in the distal portion of the body, which suggests, according to (Shine), that locomotion may be prioritized over reproductive investment. The same pattern was observed in Philodryas olfersii, one arboreal representative of this genus, in which follicles are smaller than in other species of the same genus that also includes terrestrial members, probably due to the increased importance of body balance in trees compared to reproduction (Fowler \& Salomão, 1994).

Tropical ophidian faunas show great morphological variety, probably owing to the adaptations presented in the occupation of diverse microhabitats (Guyer \& Donnelly) as well as the variability of ecological niches, foraging strategies and diet (Kauffman \& Gibbons, 1975). However, available data in the literature on ecomorphology take into consideration just some of the corporal variables, besides mentioning only the position of the heart and not any of other internal organs. The results here presented on I. cenchoa reinforce the importance of investigating the greatest possible number of internal corporeal variables, so that we can infer from physiological, ecological and behavioral aspects of a certain species or a group of serpents.

In general, the posterior position of all internal organs is linked to a habitat specialization of a snake (Martínez et al., 1985). Our data corroborate this idea, linking the arboreal species $I$. cenchoa with a relatively posterior internal topography.

\section{Acknowledgements}

We would like to thank FAPERJ (Proc. No E-26/ 171.310/2001; $\quad N^{\circ}$ E-26/170.654/04), Programa PROCIÊNCIA/UERJ, CNPq and CAPES for the financial support, Prof. Dr. Heitor Evangelista (UERJ), Prof. Dr. Ronaldo Fernandes (MNRJ) and Valdir José Germano (Instituto Butantan) for technical support. CR-BIO 02085.

AVEIRO-LINS, G.; ROCHA-BARBOSA, O.; SALOMÃO, M. G.; PUORTO, G. \& LOGUERCIO, M. F. C. Anatomía topográfica de la serpiente bejucillo cabezona, Imantodes cenchoa (Linnaeus, 1758) (Colubridae: Xenodontinae). Int. J. Morphol., 24(1):43-48, 2006.

RESUMEN: Imantodes cenchoa (Duméril, 1853) es una serpiente xenodontinea, arbórea, noctura y ovípara, que se alimenta de anfibios y largartos. Se encuenta en América Central y del Sur, incluyendo las partes Norte y Central de Brasil. En este trabajo, investigamos la relaciones entre la Anatomía Topográfica y hábitat en I. cenchoa. Fueron examinados 20 especímenes (13 hembras no preñadas y 7 machos). El estudio de la Anatomía Topográfica fue realizada a través de observaciones de la anatomía interna, particularmente la posición y tamaño del pulmón, corazón, hígado, gónadas y riñones derechos e izquierdos. Los resultados mostraron que todos los órganos están localizados en una posición posterior, en relación a la entrada de la longitud del hocico(SVL). El centro de gravedad se encuentra a 74\% de SVL en machos y hembras. En los machos, no fue observada alometría positiva entre la posición de los órganos. Fue observada alometría negativa en las hembras, considerando la posición del extremo anterior del riñón izquierdo, los extremos anterior y posterior del riñón derecho y ambos ovarios. En machos, se presentó alometría negativa en la posición de todos los órganos. La distancia entre el último folículo y la cloaca fue $8.78 \%$ de SVL. Nuestros datos corroboran la idea que la posición posterior de todos los órganos internos está marcada por una especialización al hábitat de una serpiente, marcando la especie arbórea I. cenchoa con una especial topografía interna posterior. 


\section{REFERENCES}

Badeer, H. S. Anatomical position of heart in snakes with vertical orientation: a new hypothesis. Comp. Biochem. Physiol., 119:403-5, 1998.

Cadle, J. E. \& Greene, H. W. Phylogenetic patterns, biogeography, and the ecological structure of Neotropical snake assemblages. In Species diversity in ecological communities: historical and geographical perspectives. Ricklefs, R. E. \& Schluter, D. (Eds.). Chicago, The University of Chicago Press, 1993. pp 281-93.

Fowler, I. R. \& Salomão, M. G. A study of sexual dimorphism in six species from the colubrid snake genus Philodryas. The Snake 26:117-22, 1994.

Gomes, N. \& Puorto, G. Atlas anatômico de Bothrops jararaca (Wied, 1824) (Serpentes: Viperidae). Mem. Inst. Butantan., 55:69-100, 1993.

Gomes, N.; Puorto, G.; Buononato, M. A. \& Ribeiro, M. F. M. Atlas anatômico de Boa constrictor Lineus, 1758 (Serpentes: Boidae). São Paulo, Instituto Butantan, 1989.

Gould, S. J. Allometry and size in ontogeny and phylogeny. Biol. Rev., 41:587640, 1966.

Greene, H. W. Snakes: the evolution of mystery in nature. Berkley, The University of California Press, 1997.

Guyer, C. \& Donnelly, M. A. Length-mass relationships among an assemblage of tropical snakes in Costa Rica. J. Trop. Ecol., 6: 65-76, 1990.

Henderson, R. W. \& Nickerson, M. A. Observations on the behavioral ecology of three species of Imantodes (Reptilia, Serpentes, Colubridae). $J$. Herpetol., 10:205-10, 1976.

Huxley, J. S. Problems of relative growth. London, Methuem, 1932.

Kauffman, G. A. \& Gibbons, J. M. Weight-length relationships in thirteen species of snakes in southeastern U.S.A. Herpetologica, 31:31-7, 1975.

Landry, M. J.; Langebartel, D. A.; Moll, E. O. \& Smith, H. M. A collection of snakes from Volcan Tacana, Chiapas, México. J. Ohio Herpetol. Soc., 5:93-101, 1966.

Lillywhite, H. B. Behavioral control of arterial pressure in snakes. Physiol. Zool., 58(2):159-65, 1985a.

Lillywhite, H. B. Postural edema and blood pooling in snakes. Physiol. Zool., 58(6):159-65, 1985b.

Lillywhite, H. B. Circulatory adaptation of snakes to gravity. Am. Zool., 27:81$95,1987 \mathrm{a}$.

Lillywhite, H. B. Snakes under pressure. Nat. Hist., 96(1):58-66, 1987b.

Lillywhite, H. B. Snake, blood circulation and gravity. Sci. Am. 259:92-8, 1988.

Lillywhite, H. B. Orthostatic intolerance of viperid snakes. Physiol. Zool., 66(6):1000-14, 1993

Lillywhite, H. B. \& Henderson, R. W. Behavioral and functional ecology of arboreal snakes. In Snakes: ecology and behavior. Seigel, R. A. and Collins, J. T. (Eds.). New York, McGraw-Hill, 1993. pp 1-48.

Lillywhite, H. B. \& Smits, A. W. The cardiovascular adaptations of viperid snakes. In Biology of pitvipers, 1992. pp 143-53,
Manzani, P. R. Ação da gravidade e sistema cardiovascular em serpentes: Hábito ou Filogenia? Rio Claro, São Paulo, Universidade Estadual Paulista, 1995.

Martínez, D. R.; Lucio, J. A. \& Schwartz, A. Topografia interna de las culebras del genero Uromacer (Colubridae). Caribaea, 1:48-59, 1985

Peters, J. A. and Orejas-Miranda, B. Catalogue of the Neotropical Squamata. Parte I. Snakes. Reprint of United States National Museum Bulletin, 297:1347,1970

Pough, F. H.; Andrews, R. M.; Cadle, J. E.; Crump, M. L.; Savitzky, A. H. \& Wells, K. D. Herpetology. Prentice Hall, 1998.

Robinson, D. C. Herpetofauna bromelícola costarricense y renacuajos de Hyla picadoi Dunn, Historia Natural de Costa Rica. In Biologia de las Bromelias. Gómez, L. D. (Ed.), Museo Nacional de Costa Rica, 1977. pp 31-43.

Rocha-Barbosa, O.; Salomão, M. G.; Puorto, G.; Laporta-Ferreira, I. L. \& Mandarim-de-Lacerda, C. A. Allometry and morphology of the heart in Oxyrhopus guibei Hoge \& Romano, 1977 (Serpentes: Colubridae). Biomed. Res., 10:35-40, 1999.

Rocha-Barbosa, O., Salomão, M. G., Puorto, G., Laporta-Ferreira, I. L. and Mandarim-de-Lacerda, C. A. Allometry and ecology of the Oxyrhopus guibei Hoge \& Romano, 1977 (Serpentes: Colubridae). Biomed. Res., $11: 259-64,2000$.

Shine, R. Constraints on reproductive investiment: a comparison between aquatic and terrestrial snakes. Evolution, 42:17-27, 1988.

Sokal, R. R. \& Rohlf, F. J. Biometry: the principles and practice of statistics in biological research. W.H. Freeman and Company, 1995.

Teissier, G. La relation d'allométrie: sa signification statistique et biologique. Biometrics, 4:14-48, 1948

Vitt, L. J. \& Vangilder, L. D. Ecology of a snake community in northeastern Brazil. Amphib. Reptil., 4:273-96, 1983.

Wittink, D. R. The Application of regression analysis. Boston, Allyn and Bacon Inc., 1988.

Young, A. M. Lizard eggs and snake (Imantodes) occupy "artificial bromeliads" in Costa Rican cacao plantations. Brenesia 19/20:393-6, 1982.

Zug, G. R.; Hedges, S. B. \& Sukel, S. Variation in reproductive parameters of three metropical snakes, Coniophanes fissidens, Dipsas catesbyi, and Imantodes cenchoa. Smithsonian Contribution Zoology, 300:1-20, 1979.

Correspondence to:

Oscar Rocha-Barbosa, $P$ fD

Universidade do Estado do Rio de Janeiro

Laboratório de Zoologia de Vertebrados

(Tetrapoda),

Departamento de Zoologia/UlER, PHLC sls.

5136/5156, IBRAG

Rua São Francisco Xavier, 524, Maracanã,

20550-013, Rio de Janeiro, $R \mathcal{R}$ - Brasil

e-mail:o6arbosa@uerj.br

Received: 29-09-2005

Accepted: 13-12-2005 